\title{
POBREZA E CRIMINALIDADE: A CONSTRUÇÃO DE UMA LÓGICA*
}

\author{
Silvia Helena Zanirato Martins \\ Doutoranda em História, Unesp - Assis
}

\begin{abstract}
RESUMO: Este artigo discute a associação existente entre os homens despossuídos e a criminalidade, o que remete às teorias de degenerescência e periculosidade criminal e sụas influências no Código Penal de 1940, até hoje em vigor.

ABSTRACT: This article discusses the existing association between poverty and criminality, which leads to the theories of degeneracy and criminal peril and their influences in the 1940 Penal Code, still in force.
\end{abstract}

PALAVRAS-CHAVE: Pobreza, Criminalidade, Periculosidade Criminal.

KEY-WORDS: Poverty, Criminality, Criminal Danger.

Uma socicdade se revela por intciro no tratamento de suas margens.

\section{JEAN-CLAUDE SCHMITT}

O último censo penitenciário divulgado, com os dados atualizados até junho de 1994, informa que há no Estado de São Paulo um total de 43747 sujeitos condenados cumprindo pena. Há ainda um déficit de 42 mil vagas nas casas de detenção, sendo que as cadeias e os distritos policiais estāo lotados (CENSo, 1994).

As estatísticas apresentam dados assustadores: o número de prisioneiros cresce continuadamente. Em junho havia 30536 pessoas nas detençôes e penitenciárias do Estado, além de outros 13211 que cumpri-

* Pesquisa financiada pela FAPESP am pena irregularmente, detidos em cadeias e distritos policiais. Entre as causas da condenação, o roubo e o furto simples chegam a atingir $38 \%$ dos crimes praticados; seguindo estes motivos, o roubo com o emprego de arma corresponde a $19 \%$ das causas da prisāo. A porcentagem de presos que reincidiram no mesmo crime atinge a marca de $33 \%$, enquanto que a reincidência pelo cometimento de delito diferente daquele que causou a prisão inicial chega a $16 \%$.

Os dados divulgados permitem traçar o perfil sócio-econômico do homem condenado: natural do Estado de São Paulo, branco, jovem - na faixa etária dos 18 aos 25 anos -, solteiro. A instrução da maioria não chega até o primeiro grau escolar $(80 \%) ; 69 \%$ têm o primeiro grau incompleto e $10 \%$ sāo totalmente analfabetos. 
O tipo de crime praticado, onde o roubo e furto simples e o roubo a mão armada são majoritários, demonstra a predominância do crime contra o patrimônio sobre o crime contra a pessoa. A taxa de reincidência na prática criminal, atingindo o índice de $49 \%$, questiona quanto à eficácia da instituiçäo enquando meio de reeducação, conforme insistem os discursos oficiais.

Embora a maioria da população presa seja branca $(55 \%)$, os negros, somados aos pardos, alcançam o índice de $40 \%$ dos reclusos. Esse percentual se mostra superior à proporçāo de negros e mestiços existentes no Estado. Outra constatação gritante, que aflora diante da leitura destes dados, é a predominância do sujeito pobre entre os dctidos. O grau de instrução escolar dos prisioneiros c a percentagem daqueles que possuem bens econômicos de valor significativo (apenas $1 \%$ ), demonstram que a maioria dos prisioneiros é oriunda das classes populares.

Muito embora os dados nāo representem um retrato confiável da criminalidade, uma vez que nem todos os atos ilegais cometidos chegaram ao conhecimento das instituiçōes policiais e que outros podem ter sido ocultados, as estatísticas oficiais da criminalidade retratam, conforme nos coloca Antonio Luiz Paixão, "uma amostra dos padrōes reais de crime numa dada comunidade: 0 crime oficialmente detectado" (PAIXĀO, 1983, p. 18). Uma outra questāo colocada diz respeito à representatividade das amostras, uma vcz que "as estatísticas oficiais não apenas subestimam o volume das atividades criminosas, como também distorcem a distribuição social desta atividade, no sentido da super apresentaçāo, na populaçāo criminosa, das classes subalternas" (idem, p. 19).

Considerando as colocaçōes de Paixão, é possivel fazer uma análise dos dados divulgados, no sentido de refletir sobre a questāo da criminalidade e as tentativas até aqui vãs de controlá-la e diminuir os níveis de violência.
Os dados censitários insistem na predominância da população mais pobre entre os reclusos e contribuem para reforçar a idéia, já tremendamente disseminada na sociedade, de que a pobreza leva ao cometimento de crimes e que os locais freqüentados pelos homens pobres precisam ser vigiados, pois ali encontra-se um potencial criminoso, prestes a manifestar-se.

A predominância de crimes contra o patrimônio, como o furto e o roubo, associada à pobreza da maioria da populaçăo detida, contribui para reforçar o entendimento de que o homem pobre, para sobreviver, rouba. No tocante a esta questão, Paixão argumenta que é preciso considerar que "certas categorias sociais sc tornam mais expostas às pressōes condutivas ao desvio e à criminalidadc, portanto, mais sujeitos à inspeção policial". Nessas categorias se encontram os sujeitos "oprimidos pela miséria, que cxperimentam as desigualdades: favelados, ciesempregados, trabalhadores não especializados, entre outros marginalizados urbanos". Estes acabam sendo atraídos para atividades criminosas na medida em que percebem os ganhos do crime como superiores em relação aos benefícios de atividades legais (idem, p. 41).

Nesse mesmo entendimento, Alba Zaluar coloca que "embora as crises economicas e sociais possam ser associadas ao aumento de certos tipos de crime, a equação não se explica pela relação direta e imediata entre a baixa renda e criminalidade" (ZALUAR, 1994, p. 59). Reduzir a explicação do aumento da criminalidade às crises, acaba por levar à conclusāo de que a população pobre é compulsionada ao crime, $e$ que o pobre, se não for devidamente orientado, é um candidato natural à prisāo.

A alta incidência de pessoas pobres entre os presos pode ser explicada de duas maneiras. Uma delas é o sistema policial e judicial altamente discriminatório: pessoas que possuem bens (a maioria branca), raramente são levadas a julgamento e, quando con- 
denadas, quase nunca cumprem a pena determinada. Outra explicação aponta para as dificuldades do homem preto $\mathrm{c}$ pobre $\mathrm{em}$ escolher seu destino $\mathrm{em}$ meio a condiçōes adversas, encaminhando-se muitas vezes pelo caminho da criminalidade.

De acordo com Zaluar, a adversidade para esses homens se apresenta, entre outros fatores, na "falta de assistência do governo às famílias pobres, na po. lícia corrompida, nas atraçōes e facilidades do tráfico, no exemplo e na sedução dos bandidos da vizinhança, na revolta que o emprego de métodos violentos provoca". Além desses, a "identificaçāo do pobre como um bandido [...] torna-se um fator a mais na inclinação [...] pelo crime" (idem, 1994, p. 1.53).

Sempre detidos para averiguação, sempre humiIhados pela suspeita de culpados, sempre perseguidos como candidatos naturais ao crime, esses homens precisam provar sua inocência, pois o pobre é semprc suspcito, até que prove o contrário. Para Zaluar, a perseguição policial sobre a pobreza funciona como um dos elementos determinantes do encaminhamento desse segmento ao crime e das altas taxas dc criminalidade presentes entre os mesmos. "É sobre o pobre que a polícia concentra seu poder: comete injustiças, humilha, tortura. É o policial instruído nas técnicas repressivas que acaba por promover ainda mais a indistinçăo entre trabalhador $\mathbf{e}$ bandido ao revistar brutalmente e prender o primeiro apenas por ser preto ou pobre, apesar de trazer consigo documento instruído para diferenciá-lo do segundo" (idem, p. 157). Nesse caso, conclui Zaluar, o policial, cuja função seria de vigiar, controlar e reprimir o cometimento de crime, acaba passando por cima dos direitos civis, tornando a figura do homem negro e pobre sempre suspeita (idem).

A associação presente entre pobreza e criminalidade, indiferenciando bandido e trabalhador pobre, revcla a persistência das teorias sobre periculosidade, que ditaram moda na Europa no século XIX e ganharam destaque nos meios judiciais no Brasil, vinculan- do a figura do pobre à do criminoso em potencial.

A teoria da periculosidade social fundamentavase nas análises de Morel e Lombroso, que defendiam, a partir de experimentos biológicos, a degeneraçāo e o potencial criminoso de determinados indivíduos. A teoria da degenerescência foi formulada $\mathrm{em} 1850$ por Morel, a partir da observação sistemática dos pobres e proletários dos arredores parisienses. Esta postulava que as razōes da loucura se encontravam na degeneração do homem, que era transmitida em graus crescentes através de geraçōes (CUNHA, 1990, pp. 22-23). As determinaçōes biológicas fażiam corn que a insanidade fosse hereditariamente transmitida às geraçôes futuras, havendo estágios intermediários entre a sanidade e a loucura. A degeneração ocorria com o homem de um modo geral. Todavia, para as "classes educadas c higiênicas", a questão era colocada no rol das probabilidades, cnquanto que os pobres, por viverem em condições propícias à degeneraçāo, tornavam inevitável a transmissāo genética (idem, ibidem).

A partir do "conhecimento" das razōes da loucura, desenvolveram-se estudos médicos que vincularam-na à criminalidade. De acordo com a teoria formulada por Cesare Lombroso, a mesma degenerescência podia ser percebida nos indivíduos a caminho do crime (idem).

Professor de Medicina Legal na Universidade de Turim, Lombroso acreditava que havia algo em comum entre os criminosos, um defeito nato que, quando estimulado, levava à violência de suas açöes. Desse modo, o crime cometido era explicado em função da má formação genética e não como conseqüência das influências sociais e da personalidade. Hereditarista convicto, Lombroso acreditava que a identificação prévia dos sujeitos com essa tendência favoreceria, senão a correção, ao menos a transformação útil do criminoso nato. Essa tranformação ocorreria pelo convívio desse indi-víduo com famílias "honestas e benevolentes" (SEELIG, 1957, pp. 43-46). 
Para comprovar seus pressupostos, Lombroso realizou uma série de investigaçōes anatômicas e antropológicas nas prisōes, onde concluiu ter encontrado o criminoso nato. Este possuía características físicas e psíquicas peculiares: forma da calota craniana, capacidade do crânio, testa fugaz, maxilar inferior procidente, sombrancelhas fartas, malares salientes, orelhas grandes e deformadas, corpo assimétrico, grande envergadura dos braços, sensibilidade dolorosa diminuída, crueldade, leviandade, aversāo ao trabalho, instabilidade, despertar precoce do instinto sexual, tendência para superstição, entre outros. Para Lombroso, a maior parte dos criminosos formava um tipo antropológico unitário: "o criminoso verdadeiro (já) nasce como tal, a sociedade dá-lhc apenas as possibilidades e motivos para a manifestação da sua disposiçāo criminosa" (idem, pp. 44-45).

As teorias defendidas por Cesare Lombroso fundamentaram a Escola Positiva de Direito Penal e influenciaram geraçōes de médicos e juristas europeus, Todavia, as críticas não foram poucas, o que levou os adeptos da Escola Positiva a reavaliarem seus postulados. Para estes, as teorias sobre o criminoso nato eram válidas, mas precisavam ser ampliadas com uma concepção sociológica. Sem contrariar as formulaçōes lombrosianas, defendiam a tese de que o meio (tal qual na cultura bacteriológica), influenciava na deflagração do crime. $O$ criminoso cra um doente que cometera um delito, agindo independente de sua vontade, isto é, coagido por uma força indominável. Embora a determinação fosse biológica, o meio agia no sentido de desencadear o processo que culminaria com a loucura ou o crime, senão ambos. O método adotado por essa escola era o experimental, onde os exames atestariam a potencialidade criminosa dos sujeitos estudados e o grau de periculosidade daquele que cometeu o crime (REVISTA PENAL, vol. l, 1940).

As cidades européias que se agigantavam no século XIX constituíam um perigo, pois escondiam no anonimato das multidōes os personagens em degeneraçāo. Fazia-se necessário uma política de prevençāo, enfrentando a degeneração antes que ela contaminasse a parte sã da sociedade. Toda uma série de saberes foram acionados de modo a sanear a cidade, por meio de uma "profilaxia preservadora, voltada para a identificação e o combate aos focos da degenerescência" (CUNHA, 1986, p. 27).

Sancar a cidade, livrando-a do perigo ao qual se encontra exposta, implicava em descobrir os indiví duos que se escondiam "nas inúmeras ruelas $\mathrm{c}$ be$\cos$, nas tavernas, botequins, nos cabarés, nas habitaçōes insalubres e promíscuas da gente pobre, nas alcovas das prostitutas" (idem). Desse modo, as técnicas de combatc à degeneraçāo incidiam preferencialmente sobre os locais freqüentados pela pobreza e faziam do homem pobre um sujeito suspeito c perigoso.

Embora tenha tido grande accitaçăo, principalmente nas árcas de Medicina e de Direito, as idéias de Lombroso nāo ficaram sem críticas, levando ao surgimento de outras teorias que culminaram com a criação da Escola Clássica de Direito Pcnal. Para seus membros não havia "o criminoso nato, como variedade morfológica da espécie humana" (SEELIG, 1957, p. 46). Antes, o ato criminoso acontecia pela vontade do agente, onde a responsabilidade penal ега conseqüente da doutrina do livre arbítrio. $O$ sujeito criminoso, "agindo conscientemente, devia responder pela ação praticada" (REVISTA PENAL, vol. II, 1941).

Essas teorias criminais chegaram rapidamente no Brasil, demonstrando a atualização dos especialistas brasileiros com a produção dos centros "avançados" do saber médico e a necessidade de encontrar soluções para problemas tāo semelhantes que o país vivia com a aglomeraçāo humana. Influenciado pelas discussōes da Escola Positiva de Direito Penal, Nina Rodrigucs publicou a partir de 1890 uma série de obras de medicina legal. Também nessa linha, Clóvis 
Bevilacqua publicou, em 1896, estudos sobre a criminologia; Afrânio Peixoto, em 1899, dissertou sobre a cpilepsia e o delito; em 1889 foi criada a Associação Antropológica e de Assistência Criminal (CANCELLI, 199, p. 62). Franco da Rocha, por sua vez, introduziu as teorias lombrosianas nos estudos sobre a doença mentat em São Paulo (CUNHA, 1986, p. 29).

$A$ adoção e aplicação das teorias de degenerescência e de periculosidade, não por acaso, coincidem com as transformações que o país vivenciou ao final do século XIX. A liberaçăo da mão-de-obra escrava, a entrada maciça de estrangeiros e o desencadear do processo de urbanização trouxeram, como consequência, uma populaçāo despossuída, que se juntava nas cidades em busca de emprego e meios de sobrevivência.

O rápido crescimento urbano trazia consigo todos os problemas da falta de planejamento das cidades que se inchavam e escancaravam a desigualdade social. A multidão circulando ao longo das ruas e avcnidas constituía uma ameaça que precisava ser enfrentada. Era preciso conhecer os personagens que se espalhavam pela cidade e organizar o espaço público, evitando os perigos da aglomeração urbana que, entre outras conseqüências, anonimava os infratores sociais (idem, p. 46).

Nesse sentido, fez-se necessário empregar os saberes que esquadrinhavam o todo social e assim evitar os perigos do convívio num mesmo espaço de diferentes pessoas. $O$ planejamento urbanò requeria uma arquitetura mais racional. A engenharia sanitária precisava escoar os dejetos que se acumulavam. Era ainda preciso criar instituições de assistência pública e reaparelhar a polícia para deter os infratores sociais. A polícia, em especial, precisava ter uma ação mais precisa, de modo a separar trabalhadores e vadios, estabelccer as fronteiras entre loucos e sãos, honestos e criminosos e definir os lugares apropriados para o confinamento dos perturbadores da ordem (idem, ibidem).
Os estudos se intensificavam na tentativa de extirpar a periculosidade latente existente no meio dos homens despossuídos. Esta população constituiu objeto desses estudos e sobre a mesma elaboraramse as mais diversas análises, procurando comprovar os desvios.

De acordo com os teóricos brasileiros, aqui o potencial degenerativo era ainda mais significativo, uma vez que a população, em sua maioria, era pobre $\mathrm{e}$ mestiça. Para os especialistas, os problemas degenerativos presentes na aglomeração humana explicavam-se pela miscigenaçāo racial que o país experimentou, onde índios e negros - raças pouco desenvolvidas -, se misturaram ao branco e formaram uma nação mestiça e degenerada. O cruzamento racial inconseqüente favorecia a loucura e a criminalidade. De acordo com esse entendimento, para solucionar a pobreza e a pouca saúde da populaçăo dotada de uma "fraqueza biológica", era preciso empregar técnicas de depuração, que levariam à cura e ao progresso (SCHWARCZ, 1.993, p. 190).

Reforçando.esse entendimento, Nina Rodrigues escreveu em As Raças Humanas e a Responsabilidade Penal no Brasil:

a imprevidência que revela a nossa populaçāo mestiça em rude contraste com o extremo oposto dos brancos, silicet dos portugueses que, mesmo chegados pobres, paupérrimos em nosso país, no fim de pouco tempo são os seus grandes capitalistas (RODRIGUES, 1938, p. 187).

Para Nina Rodrigues, o problema criminal, em sua maior parte, estava no fato dos mestiços não terem "a consciência plena do direito de propriedade", pois que esta constituía "momento capital, elemento constitutivo da qualificação de criminalidade" (idem, p. 191). Para ele, o mestiço, resultado do cruzamento "inconseqüente", mostrava-se mais propício ao cometimento de atos ilegais, mesmo aqueles mais "disfarçados", ou seja, aqueles em que o predomínio dos caracteres da raça superior parecia "definitiva e soli- 
damente firmado", não era impossivel revelar-se "de um momento para o outro, o fundo atávico do selvagem" (idem, p. 209).

Esse tipo de argumentaçāo perdurou nas primeiras décadas deste século e, embora com muitos adeptos, nāo deixou de sofrer críticas daqueles que se opunham à teoria da degenerescência na mestiçagem brasileira. Pedro Lessa, já em 1900, condenava o determinismo racial presente nas análises em que se embasavam a criminologia. Para ele, essa teoria nada mais era do que "o resultado de um movimento reacionário contra as teorias humanitárias... Nāo há desenvolvimento moral e racial sem certas condiçōes de bem estar social" (SCHWARCZ, 1993, p. 179).

Na campanha presidencialista de 1918, Ruy Barbosa igualmente se contrapôs às teses racistas argumentando que os problemas do homem brasileiro se encontravam na doença e no analfabetismo que o atingiam e nāo nas origens raciais ou no caráter inato (SKIDMORE, 1.976, p. 200). A mesma questão foi levantada por Roquete Pinto, professor de antropologia do Museu Nacional, presidindo o Primeiro Congresso Brasileiro de Eugenia realizado em 1929. Naquela ocasião, Roquete Pinto criticou a forte influência racista presente na maioria dos congressistas que defendiam a aplicação da eugenia, contrapondo que o problema brasileiro era antes conseqüência da falta de higiene, e nāo um problema da raça (SCHWARCZ, op. cit, p. 96).

A influência da teoria positiva sobre os médicos e especialistas em direito penal brasileiro não foi pequena. Estes empregavam as teses da degenerescência e da periculosidade sintonizados com os especialistas europeus. Entre os nomes mais conceituados da Escola Penal Positiva e que mais influenciou os estudiosos da ciência penal, destaca-se Enrico Ferri, criminologista italiano que esteve no Brasil em 1908, quando visitou a Faculdade de Direito do Largo de Sāo Francisco, onde foi recebido com entusiasmo (idem, p. 179).
Tendo Nina Rodrigues como um de seus expoentes, a medicina brasileira reinvidicava para si "independência no tratamento do criminoso", entendido enquanto um doente que se diferenciava dos demais apenas em função do tipo específico de moléstia do qual estava acometido: o crime. Segundo esse entendimento, o criminoso era "um doente mais ou menos curável na ordem moral e também na ordem psíquica". Para sua cura, era preciso "aplicar os grandes princípios da arte médica: à diversidade dos males, deve opor-sc a variedade dos remédios" (idem, p. 211).

Para os estudiosos da medicina legal e do dircito penal, a criminalidade era o resultado da "anormalida. de física súbita, ou persistente por degenerescência, degradaçōes parciais ou gerais adquiridas de forma hereditária e por hibridaçāo". Para estes, todo criminoso era portador de "sinais lombrosianos comuns, ou específicos da hora do crime, quando se the acomete um panus de visão anterior, um cstado de obscurecimento" (idem, p. 210).

Desse modo, os estudos desdobravam-se concluindo que se o crime era conseqüência da doença da qual o homem sc achava portador, o que deveria ser investigado era o criminoso e nāo o crime. A punição que lhe cabia deveria ser definida em funçāo do perigo que o sujeito representava para a sociedade $e$ nāo em função do ato praticado. De tal concepçāo desprendiam-se questionamentos ao Código Penal em vigor desde 1893, que definia o crime como uma açāo praticada pelo livre-arbítrio do autor e assim punia a prática do crime e não visava o criminoso.

"A legislaçāo penal brasileira", argumentava Nina Rodrigues, "adotou uma concepção espiritualista de uma mesma alma, de uma mesma natureza em todos os povos, tendo como conscqüência uma mesma inteligência e uma mesma capacidade em todas as raças". "Por ventura", indagava o mesmo, "pode-se conceder que a consciência do direito e do dever que têm essas raças inferiores seja a mesma que possui a 
raça branca civilizada?’ A resposta a essa questāo não podia ignorar os conhecimentos das ciências biológicas e as diferenças raciais por ela confirmadas, concluía Nina Rodrigucs (RODRIGUES, 1938, p. 145).

"O Código Penal está errado, vê o crime e nāo o criminoso", defendiam em coro os especialistas em direito penal identificados com as teorias da escola positiva. Para estes a natureza do delito era, sem dúvida, "de ordem secundária". Antes de tudo, era preciso "a identificação mental dos criminosos, pela inspeção médica-física e psíquica e sua qualificação à espécie a que pertence". Na defesa de seus pressupostos, argumentavam ainda que "a ciência fechará os cárceres abrindo a correção psicológica sob a tutela de médicos que cuidarão da cura física e mental dos transviados da sociedade" (SCHWARCZ, p. 212).

A defesa da orientação médica na determinação dos destinos do criminoso e a crítica ao Código Penal perdurou por toda a década de vinte. $O$ argumento era sempre o mesmo: a doutrina do livre-arbítrio, defendida no código de 1890 , nāo fazia mais sentido diante dos estudos da criminologia e da medicina legal. Os argumentos favoráveis às mudanças vinham em prol da elaboraçāo de novos dispositivos legais que corrigissem o anacronismo do Código em vigor.

Os anos trinta, com a ascensão de Vargas ao poder e a nova orientaçāo política daquele governo, favoreceram decisivamente as mudanças tāo desejadas em relaçăo ao Código Penal.

A aceleraçāo da industrializaçāo, a urbanizaçāo crescente $\mathrm{c}$ o deslocamento populacional do campo para as cidades e do nordeste para o sudeste, desde meados dos anos trinta, levou as grandes capitais como Sāo Paulo e Rio de Janeiro a sofrerem um novo aumento populacional. A maioria da população que lá se concentrou era composta de sujeitos pobres, que iam para o "sul maravilha" na crença de que a industrialização em curso traria melhorias em suas vidas. Nem todos conseguiam os empregos esperados, pois o fluxo mostrava-se maior do que a capacidade de absorção da mão-de-obra e muitos destes sujeitos ficaram nas ruas, dependendo da caridade pública $\mathrm{e}$ de empregos esporádicos.

O crescimento da massa de despossuídos $\mathrm{e} o$ aumento da criminalidade trouxeram novamente à tona as teses defendidas pela Escola Penal Positiva quanto à associação entre o biotipo e a criminalidade. Em 1938 foi reeditado em terceira edição o livro de Nina Rodrigues, As Raças Humanas e a Responsabilidade Penal no Brasil. No prefácio desta ediçāo, Afrânio Peixoto chamou a atenção para a importância da publicaçāo naquele momento em que se elaborava um novo Código Penal, uma vez que as idéias ali apresentadas poderiam certamente contribuir para esse fim (RODRIGUES, 1938).

A reediçāo desta obra, que mostra o continuar da preocupação com a responsabilidade penal do homem que delinqüiu, coincide com as discussōes sobre a criação do Instituto de Biotipologia Criminal na Penitenciária de São Paulo, que ocorre em dezembro de 1939. Se a Biotipologia era entendida enquanto a ciência das constituiçōes, temperamento e caracteres dos homens, a Biotipologia Criminal era a ciência da constituição, do temperamento e do caráter do homem delinqüente (REVISTA PENAL, vol. I, 1940).

Embora os especialistas salientassem que a Biotipologia Criminal alj praticada fosse uma mescla das teorias das Escolas Penais Positiva e Clássica, podemos perceber que as práticas científicas desenvolvidas confirmavam a força da teoria positiva presente atê entāo.

Na inauguração do Serviço de Biotipologia Criminal, o Secretário da Justiça de São Paulo, José de Moura Resende, cxpôs as razōes para o seu funcionamento, salientando que

as condiçōes da vida moderna, nas suas múltiplas manifestações imprevisíveis e inospitáveis, exigem a mais experimentada plasticidade dos governantes; impōem surpreeendentes ajustes biológicos e sociais, de aspectos intensivo e 
francamente evolutivo. [De acordo com suas palavras, era urgente pensar] biotipologicamente no desejo brasileiro de melhorar a nossa raça. [Para isso cabia ao lnstituto atentar para] os indivíduos atropelados ao longo da vida, ou tangidos pelo atavismo, pelas taras hereditárias e com uma definitiva tendência para o crime, [que] exigem, como já aconselhava Morel, uma observaçāo muito atenta e um tratamento especial de reparação, num combate acérrimo aos seus estigmas de degenerescência (REVISTA PENAL, $2^{\circ}$ scmestre, 1940, p. 501).

Na mesma ocasiāo, o diretor médico do Instituto, José Carlos da Silva Telles, colocou que os trabathos ali desenvolvidos consistiam na "observaçāo cuidadosa e meticulosa da individualidade do delinqüente", de modo a certificar-se do grau de periculosidade que este continha. Uma vez constatada a periculosidade do sujeito, cabia salvaguardar a coletividade dos atos anti-sociais que este cometeria, aplicando as medidas penais cabíveis. A periculosidade social era entendida como "a manifesta capacidade de uma pessoa cometer um delito, ou a probabilidade de vir a ser autor de um crime". Desse modo, os exames desenvolvidos nos laboratórios permitiriam verificar a periculosidade dos sujeitos, revelando "o grau de potencialidade perigosa, capaz de se revelar através de açōes anti-sociais num futuro próximo, ou remoto" (REVISTA PENAL, 1943).

Para os teóricos da biotipologia criminal, havia duas causas na gênese do crime: as causas exógenas e as causas endógenas. Colocando que não cabia ao Sèrviço de Biotipologia "impor a aceitação do "fator biológico' como causa única, ou mesmo predominante na prática do crime", contrapunham que nāo se podia admitir o inverso: "o sociologismo exagerado, como causa única da gênese do fenômeno biosocial, o crime". Era inquestionável a influência predisponente que os fatores constitucionais exerciam na gênesc do crime, que surgiam "por estímulos que, sem predisposiçāo exógena, nada fariam...." (RELAT. INST. BIOT., 1944). Nesse entendimento, a delinqüência era "muitas vezes, senão totalmente, ao menos parcialmente, um problema clínico, capaz de soluçōes médicas" (idem).

Partindo destes pressupostos, afirmavam que o funcionamento do Instituto era essencial uma vez que, por meio dos estudos ali desenvolvidos, melhor se poderia separar o delinqüente nato do adquirido, este bem mais passível de reeducaçāo. A função que cabia à instituição cra

colaborar na política criminal-penal do Estado, estudando os indivíduos na fase anti-deletiva e, portanto, atuando predominantemente na 'prevençāo criminal' corn perspec. tivas reais de sucesso e vitória da medidas técnico-científi. cas no combale à criminalidade (idem).

Considerando que os distúrbios somáticos e de naturcza psíquica predispunham ao crime, era prcciso detectar as diferenças entre os sujcitos. "Apesar dc todos os homens possuirem um corpo e uma alma, não são todos iguais, existem diferenças que procedem da diversidade da constituiçăo somática e das expressóes psíquicas", ressaltava o cndocrinologista. "Em medicina não há doença, há doentes, [...] assim também na etiologia do crime e na cura do criminoso, [pois] o criminoso é em regra um docnte", completava o clínico geral (REVISTA PENAL, vol. I, 1940).

Os sujeitos que cumpriam pena na Penitenciária constituíam o objeto de estudos do Instituto e foram analisados biológica e psicologicamente. Os trabaIhos realizados com aquela clicntela compreendiam exames antropométricos, endocrinológicos, morfológicos, dactiloscópicos, sociológicos, psicológicos e psiquiátricos. Estes estudos procuravam provar as conseqüências de disfunçōes físicas e psíquicas $\mathrm{cm}$ relação à criminalidade.

As conclusões dos exames psicológicos e psiquiátricos demonstraram que entre 6000 detentos examinados, 400 eram doentes mentais. Esse total correspondia a $7,33 \%$ dos internos. Havia entre estes, 116 esquizofrênicos e 109 psicopatas. Estes da- 
dos, comparados com a população do Estado de São Paulo - que alcançava naquele momento 7312000 habitantes e tinha um percentual de $2,5 \%$ de doentes mentais -, demonstravam a estreita relação entre o crime e a insanidadc mental (REVISTA PE. NAL, n. 2, 2" sem., 1940).

Apesar dos dados indicarem que mais de $90 \%$ da populaçāo penitenciária podia ser considerada normal, os especialistas do Instituto de Biotipologia questionavam: "o que é ser normal"?, "Numa comunidade como cssa", ponderavam,

a divisão adotada pela pedagogia entre normais e anormais nāo é suficiente. Entre os normais sāo encontrados toda uma gama de variaçōes. Há ainda os falsos anormais... $\mathrm{e}$, somente o exame biotipológico total e especialmente apurado em sua face psicológica (caráter e inteligência) permite, com mais segurança e facilidade, atingir tais objetivos (RELAT. INST. BIOT. 1944).

Outros exames foram efetuados para mostrar a relação entre a biotipologia e o comportamento criminoso. Sempre tomando como objeto de investigaçāo os internos da Penitenciária, analisou-se, entre outras questōes, a criminalidade para os portadores de sifilis.

A populaçẳo detida era, também naquele tempo, predominantemente composta por mestiços de branco com negro. Os exames feitos indicaram que mais da metade dos internos eram portadores de sífilis. As conclusōes dos especialistas foram de que a doença tinha uma incidência de $52 \%$ entre os leucodermos (brancos), 56,58\% entre os faiodermos (pardos) e $58,59 \%$ entre os melanodermos (escuros). Percebendo que a maioria dos portadores de sífilis era representada pelos mestiços (que por sinal constituíam a maioria da populaçāo interna), a conclusāo médica foi de que havia uma predisposição desta "raça" em adquirir a doença. Essa predisposiçâo se explicava pela promiscuidade em que viviam, onde a falta de higiene favorecia o contágio. A predisposiçāo se ex- plicava também pelo fato de "o mulato ser um produto híbrido, oriundo da miscigenação de duas raças completamente diferentes em múltiplas características biológicas". Esta mistura indevida produzira um sujeito que estava "mais predisposto e atavicamente sujeito às disfunções genéticas, mais disposto a práticas sexuais e com mais facilidade de contaminaçāo venérea" (REVISTA PENAL, vol. I, 1940).

Valendo-se de dados colhidos entre os sentenciados que cumpriam pena, cuja maioria estava presa pela prática do roubo e do furto, outra constatação do cientista foi que os efeitos nocivos da sífilis levavam "à predisposição à impulsividade, à violência reacional, à perversidade e à amoralidade". Dentro deste quadro, uma das conclusōes foi que "a sífilis predispōe o indivíduo a tendências degenerativas [pois] ataca o caráter". Outra conclusāo "cientificamente provada" foi que o sujeito atacado pela doença tinha uma tendência à pratica de crimes contra a propriedade (idem).

Os resultados obtidos através dos exames pelo Instituto de Biotipologia vinham "cientificamente" reforçar as noçōes já disseminadas da inferioridade dos negros e seus descendentes, que tinham potencial criminoso pois eram mais facilmente arrastados às paixões pelo ganho fácil, obtidos pelos meios ilícitos.

Com base em seus experimentos, os teóricos do Instituto de Biotipologia insistiam na tese de que a pena imposta pelo crime deveria ser uma medida de segurança para proteger a sociedade, impedindo que os sujeitos potencialmente perigosos permanecessem em meio ao convívio social. Se até entāo a pena havia sido prescrita em funçāo do delito praticado, agora deveria ser proporcional à periculosidade do homem que delinqüiu.

A preocupaçāo quanto ao perigo nāo deveria se ater apenas ao homem que já havia cometido o crime. Antes, as atençōes deveriam ser dirigidas para os sujeitos potencialmente perigosos, que se encontravam 
no anonimato das multidões. Estes eram apontados pela Biotipologia: "vagabundos, bêbados habituais, loucos, epiléticos, menores desocupados c sem família, deficientes ou atrasados". Todos esses eram sujeitos potencialmentc perigosos pois eram portadores de uma "latente periculosidade criminal" (CULTURA POLíTICA, ago. 1942).

A teoria da periculosidade criminal, cientificamente comprovada pelos criminologistas, foi accita pelos membros da comissāo de revisão do Código Penal, Alcântara Machado, Nelson Hungia e Francisco Campos, que incluíram csses preceitos no código em elaboração.

O novo Código Penal, que entrou em vigor em 1942, incluiu entre seus artigos a Presunçāo da Periculosidade. De acordo com o artigo 14 da Lei das Contravençōes Penais, cram presumidamente perigosos, além dos indivíduos a que se referem os $\mathrm{n}^{2}$ I e Il do artigo 78 do Código Penal (irresponsáveis mentais e os doentes mentais incapazes de entender o ato criminoso do fato), o condenado por contravençāo cometida em estado de embriaguez pelo álcool ou substância de efeito análogo, quando habitual à embriaguez, c o condenado por vadiagem ou mendicância". Eram também potencialmente perigosos "os sujeitos reincidentes na prisão pelo jogo de azar, e os reincidentes no jogo do bicho" (CÓDIGO PENAL, 1940).

A periculosidade apontada pelo Código restringia-se aos homens despossuídos, uma vez que a posse de bens pelo homem detido por quase todas as contravençōes colocadas era suficiente para anular a pena a ele imposta. Mendigos, ambulantes, empregados temporários, desempregados, pessoas sem posses, formavam o grupo dos "homens perigosos", cuja vigilância precisava ser constante, pois a possibilidade de vir a ser autor de um crime era maior.

Desse modo, a teoria da periculosidade criminal, contemplada no Código Penal de 1940, até hoje em vigor, acabou por acentuar a discriminaçāo existente quanto aos homens pobres que se tornaram, legalmente, homens perigosos. A suspeita indiscriminada que se abateu sobre todos os "potencialmente perigosos", por um lado fez desaparecer as frontciras entre trabalhador e bandido, $\mathrm{c}$ por outro nāo significou a diminuiçāo dos índices de criminalidade.

Hoje convivemos com o aumento da criminalidade; com a supcrlotação das cadeias, casas de detençāo e penitenciárias; com a violência policial que tem matado indiscriminadamente trabalhadores e bandidos; com a morosidade do judiciário e a falência da instituição prisional. Concluindo, resta pensar até que ponto essas teorias, contempladas no Código e disseminadas na sociedade, nāo contribuíram para reforçar a visão esteriotipada de que o homem preto e pobre é sempre o suspcito e assim acomodar a justiça a proceder uma investigação mais cuidadosa quanto ao aumento da criminalidade.

Determinar o grau de periculosidade de um sentenciado e reeducá-lo no sentido de devolvê-lo à sociedade cra o objetivo da Biotipologia. Para isso cra absolutamente necessário começar esse trabalho de reeducaçāo dentro da penitenciária.

Essa tentativa de reeducar o homem sentenciado dentro das prisōes se valeu também da aplicaçāo de preceitos morais $e$ da aprendizagem de ofício. $O$ cotidiano dos internos passou a ser minuciosamente planejado.

As atividades na prisāo deviam ser planejadas de modo a impedir a rotina, isso equivalia a estabeleccr o seguinte funcionamento: de segunda à sexta-feira o despertar ocorreria às 5:30, o café seria servido às 6:00, às 6:30 a saída para o trabalho e às 10:00 o recothimento para o almoço, que aconteceria às 11:00. Apenas $\mathbf{4 5}$ minutos para o almoço e novamente a saída para o trabalho, às $16: 30$ recolhimento para o jantar, às 17:00 o jantar, às 18:30 aulas, $e$ às 21:00 recolhimento geral, com o sinal de silêncio tocando às 21:30. 
Às quartas-feiras a rotina seria quebrada, pois das 7:00 às 10:00 previa-se aulas de educaçâo física e banho.

Aos sábados, das 7:00 às 10:00, haveria a educação física, o barbeiro e o banho. Das 15:00 às 17:00 previa-se diversão nas sessōes de cinema e teatro.

Aos domingos o dia começaria com o ofício religioso que ocuparia o período das 6:30 às 7:30; das 8:00 às 11:00 os internos receberiam as visitas da família. Entre as 11:00 e 12:00 a educação física seria acompanhada da banda de música; o almoço aconteceria às 12:00, entre 13:00 até às 15:00 haveria o recreio geral, das 15:00 às 17:00 novamente sessöes de cinema e teatro, das 17:00 às 21:00 irradiaçōes musicais e às 21:00 o sinal de silêncio.

A programação prevista pouco lembra uma instituiçào total, no sentido colocado por Michel Ignitief.

Entretanto, dentro das prisōes, o funcionamento programado do cotidiano, insistia na afirmaçāo de que "o trabalho, a disciplina $\mathrm{c}$ a bondade resgatam a falta cometida e reconduzem o homem à comunhāo social". Estes dizeres estavam escritos na fachada principal do prédio da Penitenciária, dispostos de modo que os internos diariamente tivessem contato com essas palavras e fossem fixando ainda mais seu significado.

Com a preocupação com a "regeneração moral do sentenciado", o cotidiano na penitenciária deveria estar voltado para incutir novos valores e reeducar esse homem. Esses valores seriam adquiridos através do trabalho, capaz de solucionar os males do corpo e do espírito. Por meio do trabalho obrigatório, sistemático, poder-se-ia "educar a atençāo e enrijar os músculos". Ao mesmo tempo, o exercício da atividade funcionaria como "um sedativo poderoso para o auto-erotismo e para as preocupaçōes de natureza sexual" (REVISTA PENAL, $n^{2} 2,2^{2}$ semestre de 1940).

O trabalho, tanto físico quanto mental, adquiria um valor supremo nesse processo. O trabalho men- tal, realizado por meio do aprimoramento do espírito, aconteceria através de palestras edificantes, do estímulo às leituras e das músicas destinadas aos detentos. O presídio promovia palestras com médicos e padres que insistiam no trabalho como fator de regeneração da pessoa. As leituras edificantes, seletas, tinham que conter apenas "obras de viagens, história, moral prática ou religiăo, como o Evangelho e a Imitaçāo de Cristo". Nada de romances amorosos e poesias sentimentais, pois este tipo de leitura cra "nociva" aos detentos.

Do mesmo modo, para se obter um ambiente estimulante à "regeneraçāo moral" os sentenciados deveriam ouvir música. Não uma música sentimental ou buliçosa, mas sim "sinfonias alegres como as de Schubert, Mozart, Rossini", além de "marchas militares, hinos patrióticos, cançōes à natureza e coros religiosos que elevam o pensamento à Deus". Ainda nesse intuito não poderia ser permitido que os reclusos, casados ou não, recebessem mulheres para satisfazer suas exigências sexuais, pois poderia pôr a perder todo o trabalho empenhado.

Com o espírito aliviado, todo o corpo estaria preparado para receber a disciplina do trabalho, fator de regeneraçāo e condiçāo para a volta ao convívio social.

Esta mudança, todavia, nāo ocorreria de uma vez. $\mathrm{O}$ indivíduo recolhido à penitenciária deveria passar por "estágios de aprendizagem" nesse caminho de "regeneraçāo". Esses estágios compreendiam as diferentes fases: a primeira era o isolamento celular onde deveria permanecer "meditando" seu passado, reportando-se a ele frente ao presente e assim desejando um futuro melhor. Na segunda fase teria um contato mais íntimo com a vida penitenciária, onde aprenderia um ofício nas oficinas do presídio e seria remunerado pelos trabalhos que realizasse. Essa remuneraçāo seria depositoda na Caixa Econômica à guisa de uma economia forçada, que receberia ao retornar à liberdade. Findo esse período, passaria en- 
tão a tratar com as terras que circundam o edifício no cultivo agrícola. Finalmente, na quarta fase, já com $2 / 3$ da pena cumprida, após ter demonstrado ótimo

\section{Bibliografia}

CANCELLI, Elizabeth. O Mundo da Violéncia: Repressāo c Estado Policial na Era Vargas (1930-1945). Tesc de Doutorado, Campinas, UNICAP, 1991.

II CENSO Penitenciário Nacional. São Paulo, Secretaria de Estado da Administraçāo Penitenciária, 1994.

Código Penal, Decreto-lei 2848, de 07 de dezembro de 1940, 23. ed. Sāo Panlo, Saraiva, 1985.

CUNHA, Maria Clementina P. $O$ Espclho do Mundo. Rio de Janeiro, Paz e Terra, 1986.

CUNHA, Maria Clementina. Cidadelas da Ordem. São PauJo, Brasiliense, 1990.

MÜller; Joäo Pedro. "A Doutrina de Periculosidade Criminal no Novo Código Penal do Brasil". Cultura Polttica, n. 18, agosto de 1942.

PAIXĀO, Antonio Luiz. "Crimes e Criminosos em Belo Horizonte - 1932-1978”. In: PINHEIRO, Paulo Sérgio, Crime, Violência c Podcr. Sāo Paulo, Brasiliense, 1983.

RELATÓRIO do Instituto de Biolipologia Criminal. São Paulo, Secretaria da Justiça e Negócios Interior, 1945.

REVISTA Pcnal e Pcnitcnciaria. São Paulo: Serviço de Biotipologia Criminal da Penitenciária do Estado, 1. vol., 1. semestre de 1940. procedimento no irabalho, poderia usufruir do livramento condicional (REVISTA PENAL E PENITENCIÁRIA, $1^{\circ}$ semestre 1940).

REVISTA Penal c Penitenciória. Sāo Paulo, Serviço de Biotipologia Criminal da Penitenciária do Estado, 2. vol., 2. semestre de 1940.

REVISTA Pcnal c Penitenciaria. Sāo Paulo, Serviço de Biotipologia Criminal da Penitenciária do Estado, Il volume, 1.e 2. semestres de 1941.

REVISTA Pcnal c Penilenciária. São Paulo, Serviço de Biotipologia Criminal da Penitenciária do Estado, III volume, 1. e 2. semestre de 1942.

REVISTA Penal c Pcnitenciária. São Pnulo, Serviço de Biotipologia Criminal da Penitenciária do Estado, IV, V, VI, VII e VIII volumes, 1943-1947.

RODRIGUES, Nina. As Raças Humanas e a responsabilidadc Penal no Brasil. Sáo Paulo, Nacional, 1938.

SCHWARCZ, Lilia Moritz. O Espctáculo das Raças. Sāo Paulo, Cia da Letras, 1993.

SEELIG, Ernest. Manual de Criminologia, I. volume. Coimbra, Arménio Amado, 1957.

SKDMORE, Thomas. Preto no Branco. Rio de Janeiro, Paz e Terra, 1976.

Zaluar, Alba. Condominio do Diabo. Rio de Janeiro, Revan/Ed. UFRJ, 1994. 